\title{
Effects of Antipsychotic Drugs on Neurogenesis in the Forebrain of the Adult Rat
}

\author{
Hui-Dong Wang',*, Floyd D Dunnavant', Tabitha Jarman' and Ariel Y Deutch' \\ 'Departments of Psychiatry and Pharmacology, Vanderbilt University Medical Center, Nashville, TN, USA
}

\begin{abstract}
The generation of new cells in the adult mammalian brain may significantly modify pathophysiological processes in neuropsychiatric disorders. We examined the ability of chronic treatment with the antipsychotic drugs (APDs) olanzapine and haloperidol to increase the number and survival of newly generated cells in the prefrontal cortex (PFC) and striatal complex of adult male rats. Animals were treated with olanzapine or haloperidol for 3 weeks and then injected with 5-bromo-2'-deoxyuridine (BrdU) to label mitotic cells. Half of the animals continued on the same APD for two more weeks after BrdU challenge, with the other half receiving vehicle during this period. Olanzapine but not haloperidol significantly increased both the total number and density of BrdU-labeled cells in the PFC and dorsal striatum; no effect was observed in the nucleus accumbens. Continued olanzapine treatment after the BrdU challenge did not increase the survival of newly generated cells. The newly generated cells in the PFC did not express the neuronal marker NeuN. Despite the significant increase in newly generated cells in the PFC of olanzapine-treated rats, the total number of these cells is low, suggesting that the therapeutic effects of atypical APD treatment may not be due to the presence of newly generated cells that have migrated to the cortex.

Neuropsychopharmacology (2004) 29, 1230-1238, advance online publication, I4 April 2004; doi: I0.1038/sj.npp. I 300449
\end{abstract}

Keywords: BrdU; dentate gyrus; haloperidol; nucleus accumbens; olanzapine; prefrontal cortex; striatum

\section{INTRODUCTION}

It now is clear that various forms of structural plasticity, including the generation of new neurons and glia, are ongoing processes in the mammalian adult brain (Gross, 2000). Most studies of neurogenesis have focused on the dentate gyrus (DG) of the hippocampus, where a significant number of newly generated neurons are seen in adult rodents and primates, including humans (Kuhn et al, 1996; Eriksson et al, 1998; Nilsson et al, 1999). Less clear is whether newly generated cells in the cortices of normal adult primates are neurons or other types of cells (Gould et al, 1999b; Kornack and Rakic, 2001; Bernier et al, 2002; Koketsu et al, 2003).

Neurogenesis and gliogenesis can be induced in the adult brain by environmental manipulations and various pharmacological treatments (Kempermann et al, 1997; Gould et al, 1999a; Nilsson et al, 1999; Yang et al, 2002; Ehringer and Kempermann, 2003). These studies have led to the

*Correspondence: Dr H-D Wang, Psychiatric Hospital at Vanderbilt, Suite 313, 1601 23rd Avenue South, Nashville, TN 37212, USA, Tel: + I-615-327-7080, Fax: + |-615-322-1901,

E-mail: huidong.wang@vanderbilt.edu

Received 23 September 2003; revised 18 February 2004; accepted 19 February 2004

Online publication: I March 2004 at http://www.acnp.org/citations/ Npp030 I0403436/default.pdf suggestion that the generation of new cells may modify pathophysiological processes in some neuropsychiatric disorders. This idea has been best explored in depression, which is linked to a decrease in neurogenesis in the DG, while treatment with various antidepressants increases neurogenesis in this region (Brown et al, 1999; Jacobs et al, 2000; Malberg et al, 2000; Duman et al, 2001; Kempermann, 2002; Santarelli et al, 2003).

These considerations have fueled speculation that similar changes may be involved in the therapeutic actions of antipsychotic drugs (APDs) in schizophrenia (Konradi and Heckers, 2001). In vivo imaging studies have reported decreased prefrontal cortical volume in schizophrenia (Hirayasu et al, 2001; Selemon et al, 2002), and a recent multicenter study of first-episode schizophrenic subjects has concluded that treatment with the atypical APD olanzapine, but not a typical APD, slows the progressive loss of gray matter volume (Lieberman et al, 2003a). A slowing or reversal of the cortical volume loss in schizophrenia by appropriate APD treatment could involve an increase in the number of newly generated cortical cells.

Wakade et al (2002) recently reported that the atypical APDs olanzapine and risperidone, but not the typical APD haloperidol, increased the number of newly generated cells in the subventricular zone (SVZ) of rats. Their study focused on the SVZ, from which cells destined to migrate to distal targets derive, but did not examine any parenchymal 
sites. As therapeutic effects attributable to neurogenesis may reflect actions in specific brain regions to which cells have migrated from the SVZ, we determined if chronic treatment with the atypical APD olanzapine or the typical APD haloperidol could modify the number of newly generated cells in the prefrontal cortex (PFC), striatum, or nucleus accumbens (NAS) of the rat. We also examined the DG, a region in which neurogenesis is elicited by antidepressant treatment.

\section{MATERIALS AND METHODS}

\section{Animals and Drug Treatments}

All experiments were conducted in accordance with National Institutes of Health's Guide for the Care and Use of Laboratory Animals. Male Sprague-Dawley rats (Harlan; Birmingham, $\mathrm{AL}$ ) approximately 80 days of age at the start of the experiment were maintained under a $12 \mathrm{~h}$ light-dark cycle (light on at 0600), with ad libitum access to food and water.

Animals were treated for 3 weeks with haloperidol (target dose $2.0 \mathrm{mg} / \mathrm{kg} /$ day; $n=12$ ) or olanzapine (target dose $10 \mathrm{mg} / \mathrm{kg} / \mathrm{day} ; n=12$ ), prepared in the drinking water to which $0.75 \%$ sucrose was added to enhance palatability or the sucrose vehicle $(n=6)$. The targeted drug doses were chosen on the basis of previously discussed considerations (Bubser and Deutch, 2002), modified to account for drug delivery over the full $24 \mathrm{~h}$ rather than an acute single dose. The APD concentration in the drinking solution was changed every other day, based on the fluid intake over the previous 2 days, to try to achieve the targeted dose. Average daily intakes at the end of the experiment were $1.97 \mathrm{mg} / \mathrm{kg} /$ day for haloperidol and $8.63 \mathrm{mg} / \mathrm{kg} / \mathrm{day}$ for olanzapine. After 3 weeks of APD treatment, the animals were then injected with 5-bromo-2'-deoxyuridine (BrdU), a thymidine analogue that is incorporated into DNA as bromouracil during the $S$ phase of the cell cycle (Miller and Nowakowski, 1988), in order to label newly generated cells. Rats received three intraperitoneal injections of $\mathrm{BrdU}$ $(75 \mathrm{mg} / \mathrm{kg}$, dissolved in $45 \%$ cyclodextrin in saline) spaced $8 \mathrm{~h}$ apart.

The great majority of BrdU-labeled cells in the adult die soon after their generation (Dayer et al, 2003). As it is possible that APDs may promote the survival of newly generated cells, half of the rats treated with haloperidol in the 3 weeks prior to $\mathrm{BrdU}$ injection continued to receive haloperidol for another 2 weeks $(\mathrm{H}-\mathrm{H} ; n=6)$, with the remaining half of the animals switched to vehicle for this period $(\mathrm{H}-\mathrm{V})$. A similar procedure was followed for olanzapine-treated rats, resulting in two groups of animals, $\mathrm{O}-\mathrm{O}$ and $\mathrm{O}-\mathrm{V}$ ( $n=6$ for each group). Finally, three rats not treated with any drug were injected with BrdU and then killed the following day, both to serve as a positive control and to gain some insight into the degree to which acutely generated cells were distributed. Animals were deeply anesthetized, perfused with $4 \%$ paraformaldehyde in phosphate buffer, and the brains removed and postfixed.

\section{Immunohistochemistry}

Coronal sections were cut serially through the forebrain at $50 \mu \mathrm{m}$ on a vibrating microtome. Every sixth section in series of sections through the rostrocaudal extent of the PFC, precommissural striatal complex, and dorsal hippocampus was processed to reveal BrdU-labeled cells using immunoperoxidase methods. Sections were incubated in $1 \%$ hydrogen peroxide in $50 \mathrm{mM}$ Tris-buffered saline (TBS) for $10 \mathrm{~min}$, rinsed in $0.2 \%$ Triton $\mathrm{X}-100$ in TBS for $15 \mathrm{~min}$, and then incubated for $30 \mathrm{~min}$ in $2 \mathrm{~N} \mathrm{HCl}$ in order to access the BrdU (Miller and Nowakowski, 1988) before being neutralized in $0.1 \mathrm{M}$ sodium borate buffer $(\mathrm{pH}$ 8.5). The sections were incubated in $4 \%$ normal horse serum for $30 \mathrm{~min}$ to reduce nonspecific staining, after which they were incubated in mouse anti-BrdU (1:1000; BD Bioscience Pharmingen, San Diego, CA) for 2 days at $4^{\circ} \mathrm{C}$. The sections were then incubated in biotinylated donkey anti-mouse (1:1000; Jackson ImmunoResearch Laboratory, West Grove, PA) followed by streptavidin-HRP (1:1600; Jackson) for $90 \mathrm{~min}$, and visualized using diaminobenzidine containing $0.3 \%$ cobalt chloride $/ 3 \%$ nickel ammonium sulfate with hydrogen peroxide to yield a black reaction product.

To examine the distribution of BrdU-labeled cells in the striosome (patch) and matrix compartments of the striatum, sections were processed to reveal BrdU using the immunoperoxidase method described above, and then incubated overnight in a rabbit anti- $\mu$-opioid receptor antibody (1:20000; Diasorin, Inc., Stillwater, MN). The sections were incubated in donkey anti-rabbit $\operatorname{IgG}(1: 100$, Jackson ImmunoResearch Laboratories) followed by rabbit PAP (1:200; Sternberger Monoclonals Inc., Lutherville, MD), and developed in diaminobenzidine to yield a brown reaction product.

Other sections were developed using an immunofluorescent double-labeling protocol to determine if BrdUlabeled cells were neurons. Sections were incubated for 2 days in a cocktail of antibodies directed against neuronal marker NeuN (1:200; Chemicon, Temecula, CA) and BrdU (1:100; Serotec Ltd, Kidlington, Oxford, UK). The sections were then washed and incubated in a mixture of Cy2conjugated anti-rat IgG and Cy3-conjugated anti-mouse secondary antibodies (1:200; Jackson ImmunoResearch), washed, mounted, and coverslipped.

\section{Data Analysis}

Brain sections were viewed under a microscope and the image was imported into NIH Image 1.62. The borders of the relevant brain area were outlined and the area occupied was calculated and expressed in $\mathrm{mm}^{2}$. The regions examined were the PFC (prelimbic and infralimbic areas), NAS (core and shell), dorsal precommissural striatum (except for the area with $150 \mu \mathrm{m}$ of the ventricular wall), and DG. BrdU-labeled cells were counted in every sixth section collected through the entire region of interest. The number of cells per section were determined and multiplied by six to estimate the total number of cells. The density of BrdU-labeled cells (number of cells $/ \mathrm{mm}^{2}$ ) was also calculated. The cell counting and calculations were carried out by a person unaware of the treatment condition of the animal. Data were analyzed using analysis of variance (ANOVA) 
with subsequent LSD tests when indicated. A $\chi^{2}$ test was used to compare the percentages of BrdU-labeled cells in the striatal patch and matrix.

Confocal microscopy was used to evaluate if BrdU-labeled cells also expressed NeuN. Images of BrdU- and NeuNimmunoreactive elements were obtained on a Zeiss LSM510 laser scanning confocal microscope and merged. Using the Zeiss LSN Image Browser 3.20, the images were rotated in three dimensions to determine if the BrdU-labeled nucleus was localized to one cell and not to an underlying or adjacent cell (see Kornack and Rakic, 2001).
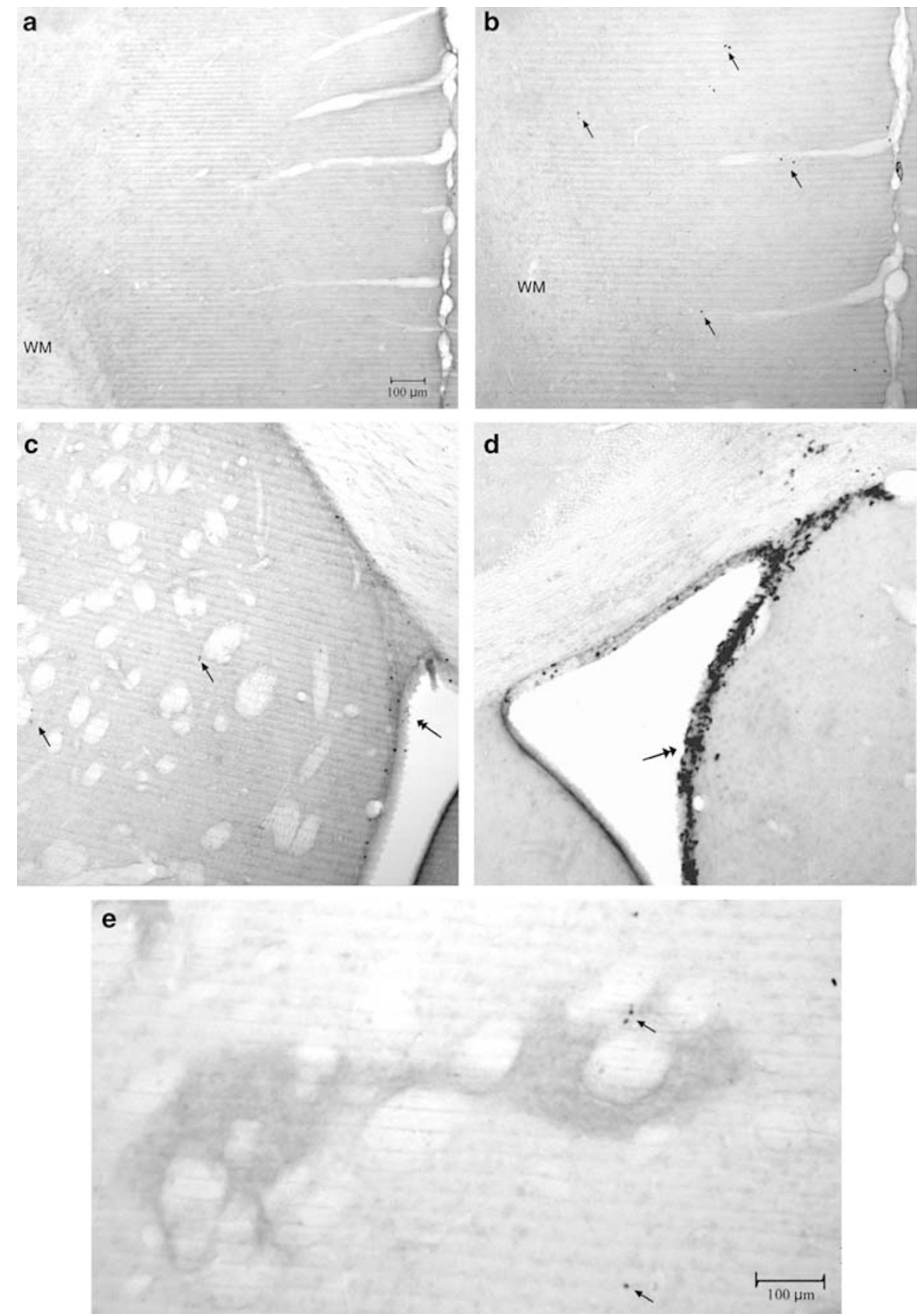

Figure I Representative photomicrographs of BrdU-labeled cells in the forebrain. Few BrdU-labeled cells are seen in the medial PFC of a vehicle-treated animal (a). In contrast, many BrdU-positive cells are seen in the PFC of a rat treated with olanzapine for 5 weeks (arrows, b). Fewer BrdU-labeled cells are seen in the striatum (c) of an olanzapine-treated rat. The SVZ of an animal treated with BrdU and killed the next day is filled with BrdU-labeled (double arrows) cells (d), many more than are seen in (c), in which the animal was killed 2 weeks after BrdU challenge. BrdU-positive cells (arrows) are seen in both the $\mu$-opioid-receptor-immunoreactive patch (darker gray) and matrix (lighter surround) of animals treated with olanzapine (e). 


\section{Prefrontal Cortex}

BrdU-labeled cells were seen throughout the medial wall of the PFC of the vehicle-treated rats, but were somewhat more frequently encountered in the ventral part of the PFC. Thus, the average density of BrdU cells in the infralimbic cortex was $2.25 \pm 0.69$ cells $/ \mathrm{mm}^{2}$, in the prelimbic cortex $1.70 \pm 0.56$ cells $/ \mathrm{mm}^{2}$, and $0.82 \pm 0.24$ cells $/ \mathrm{mm}^{2}$ in the shoulder cortex (see Figure 1). Chronic administration of

Total Number of BrdU-Labeled Cells

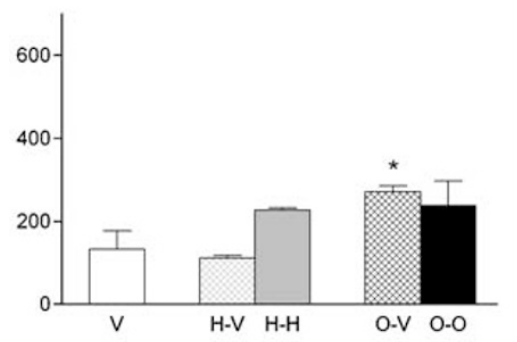

PFC

olanzapine but not haloperidol increased the number of BrdU-labeled cells $\left(\mathrm{F}_{4,19}=3.29, p=0.032\right)$ and the density of BrdU-labeled cells $\left(\mathrm{F}_{4,21}=4.09, p=0.013\right)$ in the PFC (see Figures 1 and 2). Rats treated with olanzapine for 3 weeks and subsequently with vehicle for the 2 weeks after BrdU injection $(\mathrm{O}-\mathrm{V})$ displayed a significant increase in the total number and the density of BrdU-labeled cells compared to the vehicle-treated control rats (Figure 2). In those animals treated with olanzapine for the 3 weeks prior to $\mathrm{BrdU}$

\section{Number of BrdU-Labeled Cells $/ \mathrm{mm}^{2}$}

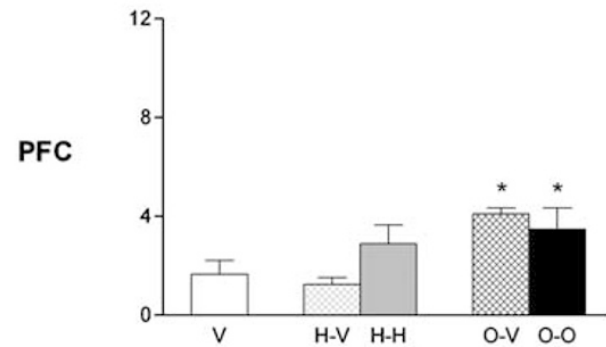

CP

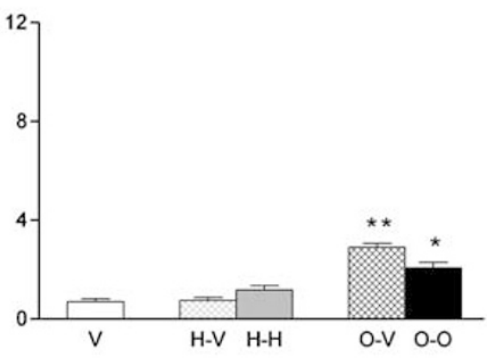

NAS

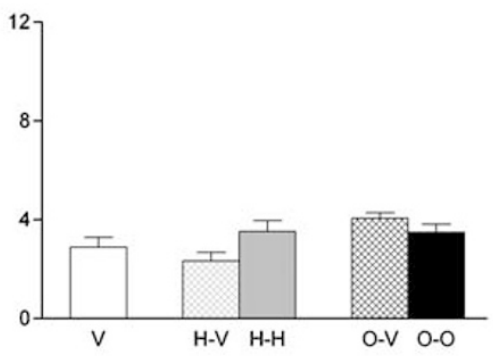

DG

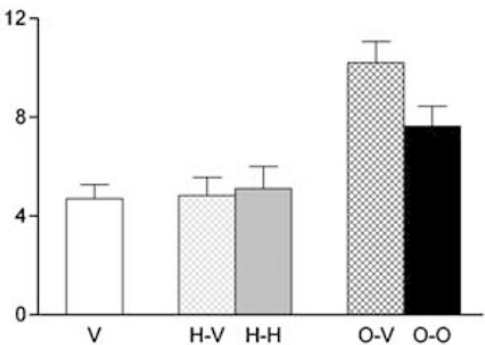

Figure 2 Effects of haloperidol and olanzapine on the total number (left) and the density (right) of BrdU-labeled cells in PFC, striatum (CP), NAS, and DG. Animals treated with haloperidol for 3 weeks, injected with BrdU on day 21 , and then treated with vehicle for 2 additional weeks are designated as $H-V$. The group of similarly treated olanzapine rats is designated as $\mathrm{O}-\mathrm{V}$. Animals that received haloperidol and olanzapine both before and after BrdU injections are labeled $\mathrm{H}-\mathrm{H}$ and $\mathrm{O}-\mathrm{O}$, respectively. $* p<0.05$, $* * * 0.0$ I relative to vehicle-treated animals $(\mathrm{V})$. 
challenge and then continued on olanzapine for 2 additional weeks (O-O), the density of BrdU-labeled cells was significantly increased. There was a trend toward an increase in the total number of BrdU-treated cells that did not reach statistical significance $(p=0.0542)$. No increase in either the total numbers or densities of BrdU-labeled prefrontal cortical cells in haloperidol-treated $(\mathrm{H}-\mathrm{V}$ and $\mathrm{H}-\mathrm{H}$ ) rats was found (Figure 2).

Examination of dual-label immunofluorescence material failed to demonstrate newly generated (BrdU) cells with a neuronal phenotype (NeuN) in the PFC (see Figure 3).
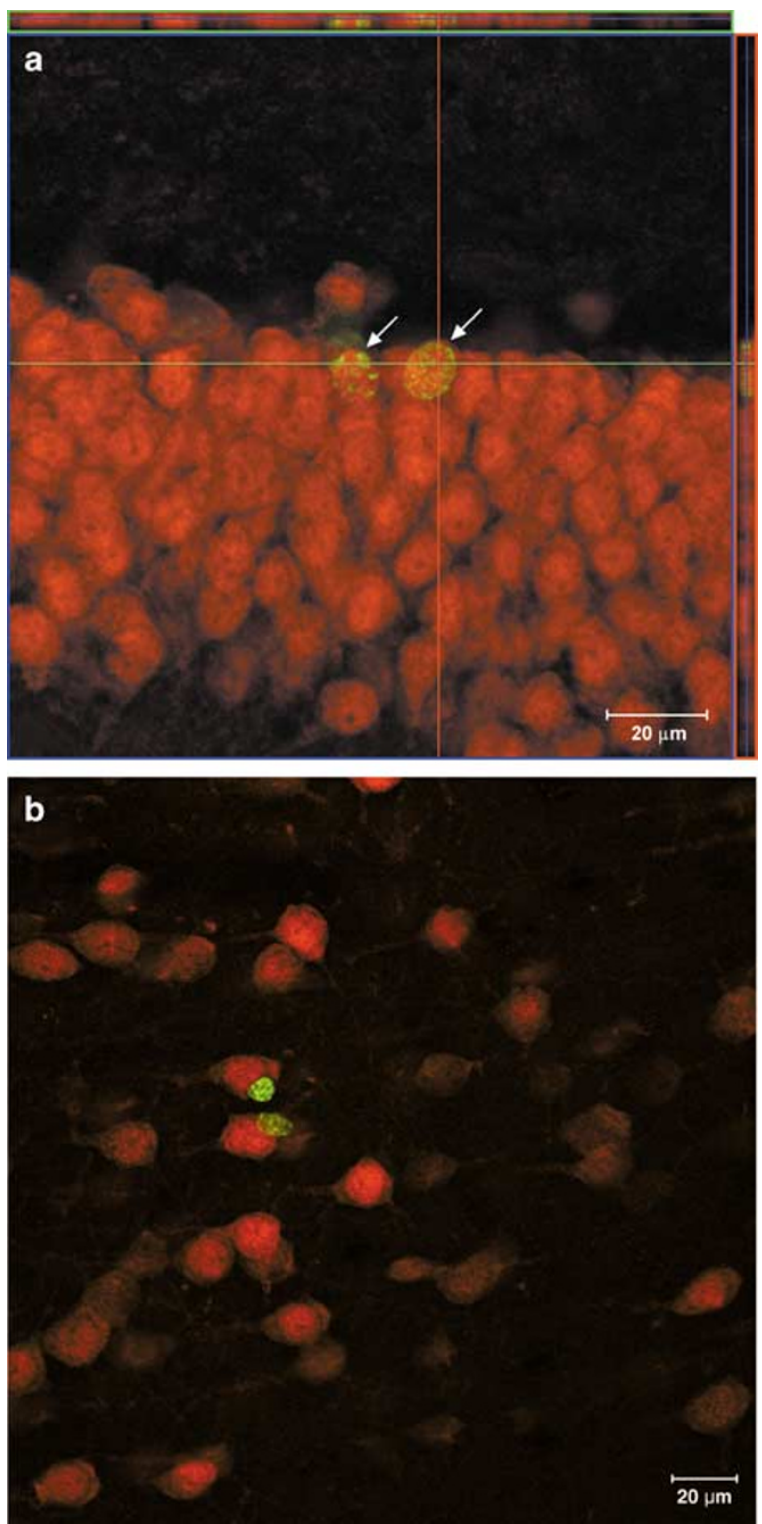

Figure 3 Confocal images of $\mathrm{BrdU}$ (green)- and $\mathrm{NeuN}$ (red)-labeled cells in the DG (a) and PFC (b) of adult rats treated with olanzapine. BrdUpositive cells with a neuronal phenotype (yellow-orange), as reflected by NeuN immunoreactivity, are observed in the DG (arrows), but not in the PFC, where BrdU-immunoreactive nuclei are located near but not coincident with NeuN.

\section{Striatal Complex}

Cells containing BrdU were observed in both the dorsal and ventral striatum. In the dorsal striatum (caudatoputamen) of the vehicle-treated rat, there appeared to be a crude rostrocaudal gradient in the density of BrdU-labeled cells. However, the variability precluded any statistically significant differences from being uncovered (anterior striatum (AP: +1.6 according to the atlas of Paxinos and Watson, 1998): $1.29 \pm 0.6 \mathrm{BrdU}$ cells $/ \mathrm{mm}^{2}$; central striatum (AP: $-0.26): 0.70 \pm 0.25$; posterior striatum (AP: - 1.30): $0.46 \pm 0.18)$. There were no differences in the density of BrdU-labeled cells between the medial $(0.98 \pm 0.27 \mathrm{BrdU}$ cells $\left./ \mathrm{mm}^{2}\right)$ and the lateral $(1.02 \pm 0.46)$ striaturm (at AP: $-0.26)$.

ANOVA revealed overall significant increases in the number $\left(\mathrm{F}_{4,21}=5.36, p=0.004\right)$ and density $\left(\mathrm{F}_{4,21}=6.90\right.$, $p=0.001)$ of BrdU-labeled cells in the dorsal striatum. Significant increases in both the total numbers and densities of BrdU-labeled cells were uncovered for both the $\mathrm{O}-\mathrm{V}$ and $\mathrm{O}-\mathrm{O}$ groups compared to the control groups. In contrast, there was no effect of haloperidol on the numbers or densities of BrdU-labeled striatal cells (see Figure 2). We did not observe any significant increase in the numbers or densities of BrdU-labeled cells in NAS of animals treated under either of the haloperidol or olanzapine protocols.

In order to determine if BrdU-labeled cells in the striatum were differentially distributed to the patch and matrix compartments, we determined the number of BrdU-labeled cells per unit area in the $\mu$-opioid-receptor-defined patch and the $\mu$-opioid-receptor-negative matrix of rats treated with olanzapine or haloperidol for the entire 5 weeks of the experimental design (see Figure 3). The percentage of the total number of striatal BrdU-labeled cells in the patch compartment was $13.2 \pm 1.5 \%$ in the olanzapine-treated rats, $10.7 \pm 0.9 \%$ for the haloperidol-treated subjects, and $17.2 \pm 0.8 \%$ for the vehicle control group. A $\chi^{2}$ test revealed no significant difference of the percent of BrdU-labeled cells in the patch compartment of either olanzapine $(p=0.30)$ or haloperidol $(p=0.08)$-treated groups compared to vehicle-injected rats.

\section{Dentate Gyrus}

BrdU-labeled cells were seen in the DG of all groups of animals. The average number of BrdU-labeled cells was significantly greater in the medial $(70.0 \pm 20.5)$ than lateral $(12.0 \pm 5.0)$ DG, but did not differ significantly between dorsal $(45.0 \pm 14.3)$ and ventral $(51.0 \pm 19.9)$ blades of the DG. Confocal microscopy revealed that some of the BrdUlabeled cells in the DG were neuronal, as reflected by colocalization with NeuN (see Figure 3). However, ANOVA revealed that $\mathrm{APD}$ treatment did not alter the numbers $\left(\mathrm{F}_{4,21}=1.39, \mathrm{NS}\right)$ or densities $\left(\mathrm{F}_{4,21}=1.86, \mathrm{NS}\right)$ of DG BrdUlabeled cells. Although visual inspection of the data suggests that olanzapine may have some effect in the DG, the lack of significance in the ANOVA does not justify a post hoc test.

\section{DISCUSSION}

Chronic administration of olanzapine but not haloperidol to adult male rats resulted in the generation of new cells that 
migrated to the PFC and striatum. Olanzapine treatment during the period after BrdU administration did not increase the survival of newly generated cells. There was no significant change in the numbers or densities of newly generated cells in NAS or DG.

\section{Distribution of Newly Generated Cells}

BrdU-labeled cells were found throughout the medial PFC and dorsal striatum of rats chronically treated with APDs.

In the medial PFC, BrdU-labeled cells were seen most frequently in the infralimbic and prelimbic cortices, with a clear ventral-to-dorsal gradient in cell number across the medial PFC. The BrdU-labeled cells of the PFC were scattered across all layers, with no apparent laminar distribution of these cells. The distributions of BrdUlabeled cells appeared to be similar in animals from different treatment conditions, suggesting that specific laminar or subareal analyses would not uncover any significant additional information.

In the dorsal striatum, there appeared to be a crude rostrocaudal gradient in the distribution of BrdU-labeled cells, consistent with a report in a non-human primate species (Bernier et al, 2002); no mediolateral gradient was apparent. In the ventral striatum, BrdU-labeled cells appeared to be more numerous in the shell of NAS than in the core, particularly in the dorsomedial shell. We were somewhat surprised to find that olanzapine but not haloperidol increased the number of newly generated cells in the dorsal striatum. Haloperidol but not atypical APDs such as olanzapine alters dopamine release and immediateearly gene expression in the dorsolateral striatum (Deutch et al, 1992; Robertson et al, 1994; Youngren et al, 1999). Moreover, treatment of psychotic patients with typical but not atypical APDs increases striatal volume (Corson et al, 1999), and typical but not atypical APDs are associated with a high rate of extrapyramidal side effects, which have long been related to striatal $D_{2}$ receptor occupancy. We therefore predicted that typical but not atypical APDs would increase the number of BrdU-labeled cells in the striatum.

The finding that olanzapine but not haloperidol increased newly generated cells in the striatum may possibly reflect nonmotor effects of olanzapine. As the striatal matrix compartment has been suggested to be associated with motor function, with the patch (striosome) more related to affective and cognitive function (Moratalla et al, 1992; White and Hiroi, 1998; Bubser and Deutch, 2002), we examined the compartmental distribution of striatal BrdUlabeled cells in olanzapine-treated rats. There was no difference across treatment conditions in the distribution of BrdU-labeled cells in the patch and matrix. Moreover, the percentages of BrdU-labeled cells in the patch and matrix agree with values predicted by the area of the striatum occupied by patch $(\sim 15 \%)$ and matrix $(\sim 85 \%)$ compartments in mammals (Johnston et al, 1990).

Consistent with the previous reports, BrdU-labeled cells in the hippocampus were relatively common in the DG; there was a clear mediolateral gradient in the numbers of BrdU-labeled DG cells, but no difference between dorsal and ventral blades of the DG.

\section{Phenotype of BrdU-Labeled Cortical Cells}

Newly generated neurons in the adult DG extend axons and form synaptic contacts with other neurons (Stanfield and Trice, 1988; Markakis and Gage, 1999). However, there is considerable controversy concerning the phenotype of newly generated cells in other areas of the brain, including neocortex. Some groups have reported that many BrdUlabeled cells in cortical regions of non-human primates are neurons (Gould et al, 1999b; Bernier et al, 2002), but these claims have been challenged by other groups who could find no evidence of neurogenesis in adult primate cortex (Kornack and Rakic, 2001; Koketsu et al, 2003). There are similar discrepancies concerning cortical neurogenesis in normal rodents (Gu et al, 2000; Jiang et al, 2001; Parent et al, 2002; Ehringer and Kempermann, 2003); most studies that have reported the presence of newly generated cells in the rodent cortex examined animals subjected to transient ischemia, that is, rodents in which there was cortical damage.

We did not observe BrdU-labeled cells in the PFC that were clearly double labeled with NeuN, using both conventional and confocal microscopy. In contrast, we observed double-labeled BrdU-NeuN cells in the DG, confirming previous studies (Eriksson et al, 1998; Ehringer and Kempermann, 2003). It is possible that we did not detect BrdU-labeled neurons in the PFC because we only examined NeuN, which is a marker of mature neurons, but not proteins such as TUC4 and double cortin, which are found in immature neurons. However, because all animals survived for 2 weeks after BrdU labeling, it is reasonable to posit that newly generated cells would have matured sufficiently during this period to expresses NeuN. We did not explore markers of different types of glia because there was insufficient tissue remaining at the end of the experiment. However, it is interesting to note that recent data suggest that there may be defects in cortical myelination in schizophrenia (Bartzokis, 2002; Davis et al, 2003b). Thus, it is possible that new oligodendrocytes induced by chronic atypical APD treatment might prove therapeutically beneficial.

\section{Survival of Newly Generated Striatal and Cortical Cells}

We treated rats with APDs for 3 weeks prior to BrdU challenge. We then either continued the APD treatment for 2 additional weeks or gave the rats vehicle during this period. This design allowed us to determine if the APD treatment increased the survival of cells that were undergoing mitosis, since most newly generated cells are transient (Gould et al, 2001). The numbers or densities of BrdUlabeled cells did not differ significantly between rats treated during the 2-week post-BrdU period and those rats that received vehicle after BrdU challenge. This suggests that atypical APD treatment, which increases the numbers of newly generated cells in the cortex and striatum, does not enhance survival of these new cells. Thus, if olanzapine reduces symptomatology by increasing newly generated cells in the cortex or striatum, continued treatment with the APD would be required to sustain therapeutic benefit. 


\section{Mechanisms of APD Actions on Genesis of New Cells}

The mechanisms that account for the ability of olanzapine but not haloperidol to increase BrdU-labeled cells in the cortex and striatum are not clear. In vitro studies suggest that dopamine inhibits cellular proliferation, as assessed by BrdU labeling, and that this effect is blocked by $\mathrm{D}_{2}$ but not $\mathrm{D}_{1}$ antagonists (Arita et al, 1998; An et al, 2003). As haloperidol is a potent $\mathrm{D}_{2}$ antagonist but does not increase BrdU-labeled cells, it is unlikely that $\mathrm{D}_{2}$ receptor antagonism accounts for the effects of olanzapine. Atypical APDs such as olanzapine have a high affinity for the $5-\mathrm{HT}_{2 \mathrm{~A}}$ receptor, but there are no data on the effects of selective 5$\mathrm{HT}_{2 \mathrm{~A}}$ agents on cell generation in the brain. Olanzapine and several other atypical APDs are also $5-\mathrm{HT}_{1 \mathrm{~A}}$ agonists, which exert antidepressant effects in animal models of depression and induce BrdU labeling in the DG (Radley and Jacobs, 2002; Santarelli et al, 2003). However, we did not find a significant increase in BrdU labeling in the DG of rats treated with olanzapine, although a trend was noted. Further work will be required to unravel the receptor mechanisms that subserve olanzapine-induced BrdU labeling in the forebrain.

\section{Functional Implications}

It is clear that the brain is far more plastic than thought previously. Among the mechanisms that can allow for remodeling of disturbed circuitry is the generation of new cells in the CNS. These cells would either have to integrate into existing neuronal circuitry, as has been demonstrated in the hippocampus (Stanfield and Trice, 1988; Markakis and Gage, 1999), or alternatively produce trophic factors or other signaling molecules that can act in a paracrine manner. We found that treatment with an atypical but not a typical APD increased the numbers and densities of newly generated cells in the PFC and striatum. The ability of olanzapine but not haloperidol to increase the generation of new cells in the cortex is consistent with the therapeutic profiles of these drugs: many but not all studies suggest that atypical APDs are more effective in reducing negative symptoms and improving cognitive function, both of which have been associated with PFC dysfunction (Meltzer and McGurk, 1999; Geddes et al., 2000; Wahlbeck et al, 2000; Bilder et al, 2002; Conley and Kelly, 2002; Bobes et al, 2003; Davis et al, 2003a,b; Gur et al, 2003; Leucht et al, 2003; Lieberman et al, 2003b; Moncrieff, 2003; Rosenheck et al, 2003; Weickert et al, 2003; Woerner et al, 2003).

The absolute number of BrdU-labeled cells in the PFC and striatum, while significantly increased in olanzapine-treated rats, is nonetheless quite small: the density of BrdU-positive PFC cells in rats treated continuously with olanzapine is about 4 cells $/ \mathrm{mm}^{2}$. It is possible that the administration of higher doses of BrdU would increase the number of cortical and striatal BrdU-labeled cells (see Cameron and McKay, 2001), or that examination at a shorter interval after BrdU challenge would reveal more cells. Continuous administration of APDs for a longer period of time might also increase the numbers of newly generated cells.

Nonetheless, the number of newly generated cells in olanzapine-treated animals is so small that it is difficult to envision that these non-neuronal elements would significantly contribute to symptomatic improvement. However, APD treatment, particularly treatment with olanzapine and other atypical APDs, causes a marked increase in the numbers of BrdU-labeled SVZ cells (Wakade et al, 2002). It is possible that these cells, which are not in brain areas thought to be involved in schizophrenia, can elaborate trophic factors and thereby elicit changes in distant areas of the brain, such as the PFC.

\section{ACKNOWLEDGEMENTS}

We thank Tamara L Altman and YueLi Zhang for their assistance in the study. This work was supported by grants MH-5124 and MH-57995 (AYD), the National Parkinson Foundation Center of Excellence at Vanderbilt University, and an unrestricted educational grant from Eli Lilly and Company (AYD). Data analysis were performed in part through the use of the VUMC Cell Imaging Core Resource supported by NIH Grants CA68485, DK20593, and DK58404.

\section{REFERENCES}

An JJ, Cho SR, Jeong DW, Park KW, Ahn YS, Baik JH (2003). Antiproliferative effects and cell death mediated by two isoforms of dopamine D2 receptors in pituitary tumor cells. Mol Cell Endocrinol 206: 49-62.

Arita J, Hashi A, Hoshi K, Mazawa S, Suzuki S (1998). D2 dopamine-receptor-mediated inhibition of proliferation of rat lactotropes in culture is accompanied by changes in cell shape. Neuroendocrinology 68: 163-171.

Bartzokis G (2002). Schizophrenia: breakdown in the wellregulated lifelong process of brain development and maturation. Neuropsychopharmacology 27: 672-683.

Bernier PJ, Bedard A, Vinet J, Levesque M, Parent A (2002). Newly generated neurons in the amygdala and adjoining cortex of adult primates. Proc Natl Acad Sci USA 99: 11464-11469.

Bilder RM, Goldman RS, Volavka J, Czobor P, Hoptman M, Sheitman B et al (2002). Neurocognitive effects of clozapine, olanzapine, risperidone, and haloperidol in patients with chronic schizophrenia or schizoaffective disorder. Am J Psychiatry 159: $1018-1028$.

Bobes J, Gibert J, Ciudad A, Alvarez E, Canas F, Carrasco JL et al (2003). Safety and effectiveness of olanzapine versus conventional antipsychotics in the acute treatment of first-episode schizophrenic inpatients. Prog Neuropsychopharmacol Biol Psychiatry 27: 473-481.

Brown ES, Rush AJ, McEwen BS (1999). Hippocampal remodeling and damage by corticosteroids: implications for mood disorders. Neuropsychopharmacology 21: 474-484.

Bubser M, Deutch AY (2002). Differential effects of typical and atypical antipsychotic drugs on striosome and matrix compartments of the striatum. Eur J Neurosci 15: 713-720.

Cameron HA, McKay RD (2001). Adult neurogenesis produces a large pool of new granule cells in the dentate gyrus. J Comp Neurol 435: 406-417.

Conley RR, Kelly DL (2002). Current status of antipsychotic treatment. Curr Drug Target CNS Neurol Disord 1: 123-128.

Corson PW, Nopoulos P, Miller DD, Arndt S, Andreasen NC (1999). Change in basal ganglia volume over 2 years in patients with schizophrenia: typical versus atypical neuroleptics. Am J Psychiatry 156: 1200-1204.

Davis JM, Chen N, Glick ID (2003a). A meta-analysis of the efficacy of second-generation antipsychotics. Arch Gen Psychiatry 60: 553-564. 
Davis KL, Stewart DG, Friedman JI, Buchsbaum M, Harvey PD, Hof PR et al (2003b). White matter changes in schizophrenia: evidence for myelin-related dysfunction. Arch Gen Psychiatry 60: 443-456.

Dayer AG, Ford AA, Cleaver KM, Yassaee M, Cameron HA (2003). Short-term and long-term survival of new neurons in the rat dentate gyrus. J Comp Neurol 460: 563-572.

Deutch AY, Lee MC, Iadorola MJ (1992). Regionally specific effects of atypical antipsychotic drugs on striatal Fos expression: the nucleus accumbens shell as a locus of antipsychotic action. $\mathrm{Mol}$ Cell Neurosci 3: 332-341.

Duman RS, Nakagawa S, Mahlberg J (2001). Regulation of adult neurogenesis by antidepressant treatment. Neuropsychopharmacology 25: 836-844.

Ehringer D, Kempermann G (2003). Regional effects of wheel running and environmental enrichment on cell genesis and microglia proliferation in the adult murine neocortex. Cereb Cortex 13: 845-851.

Eriksson PS, Perfilieva E, Bjork-Eriksson T, Alborn AM, Nordborg C, Peterson DA et al (1998). Neurogenesis in the adult human hippocampus. Nat Med 4: 1313-1317.

Geddes J, Freemantle N, Harrison P, Bebbington P (2000). Atypical antipsychotics in the treatment of schizophrenia: systematic overview and meta-regression analysis. BMJ 321: 1371-1376.

Gould E, Beylin A, Tanapat P, Reeves A, Shors TJ (1999a). Learning enhances adult neurogenesis in the hippocampal formation. Nat Neurosci 2: 260-265.

Gould E, Reeves AJ, Graziano MS, Gross CG (1999b). Neurogenesis in the neocortex of adult primates. Science 286: 548-552.

Gould E, Vail N, Wagers M, Gross CG (2001). Adult-generated hippocampal and neocortical neurons in macaques have a transient existence. Proc Natl Acad Sci USA 98: 10910-10917.

Gross CG (2000). Neurogenesis in the adult brain: death of a dogma. Nat Neurosci Rev 1: 67-73.

$\mathrm{Gu}$ W, Brannstrom T, Wester P (2000). Cortical neurogenesis in adult rats after reversible photothrombotic stroke. J Cereb Blood Flow Metab 20: 1166-1173.

Gur RE, Kohler C, Ragland JD, Siegel SJ, Bilker WB, Loughead J et al (2003). Neurocognitive performance and clinical changes in olanzapine-treated patients with schizophrenia. Neuropsychopharmacology 28: 2029-2036.

Hirayasu Y, Tanaka S, Shenton ME, Salisbury DF, DeSantis MA, Levitt JJ et al (2001). Prefrontal gray matter volume reduction in first episode schizophrenia. Cereb Cortex 11: 374-381.

Jacobs BL, Praag H, Gage FH (2000). Adult brain neurogenesis and psychiatry: a novel theory of depression. Mol Psychiatry 5: 262-269.

Jiang W, Gu W, Brannstrom T, Rosqvist R, Wester P (2001). Cortical neurogenesis in adult rats after transient middle cerebral artery occlusion. Stroke 32: 1201-1207.

Johnston JG, Gerfen CR, Haber SN, van der Kooy D (1990). Mechanisms of striatal pattern formation: conservation of mammalian compartmentalization. Dev Brain Res 57: 93-102.

Kempermann G (2002). Regulation of adult hippocampal neurogenesis - implications for novel theories of major depression. Bipolar Disord 4: 17-33.

Kempermann G, Kuhn HG, Gage FH (1997). More hippocampal neurons in adult mice living in an enriched environment. Nature 386: 493-495.

Koketsu D, Mikami A, Miyamoto Y, Hisatsune T (2003). Nonrenewal of neurons in the cerebral neocortex of adult macaque monkeys. J Neurosci 23: 937-942.

Konradi C, Heckers S (2001). Antipsychotic drugs and neuroplasticity: insights into the treatment and neurobiology of schizophrenia. Biol Psychiatry 50: 729-742.

Kornack DR, Rakic P (2001). Cell proliferation without neurogenesis in adult primate neocortex. Science 294: 2127-2130.

Kuhn HG, Dickinson-Anson H, Gage FH (1996). Neurogenesis in the dentate gyrus of the adult rat age-related decrease of neuronal progenitor proliferation. J Neurosci 16: 2027-2033.
Leucht S, Wahlbeck K, Hamann J, Kissling W (2003). New generation antipsychotics versus low-potency conventional antipsychotics: a systematic review and meta-analysis. Lancet 361: 1581-1589.

Lieberman JA, Charles HC, Sharma T, Zipursky R, Kahn R, Gur R et al (2003a). Antipsychotic treatment effects on progression of brain pathomorphology in first episode schizophrenia. Schizophr Res 60(Suppl): 293.

Lieberman JA, Tollefson G, Tohen M, Green AI, Gur RE, HGDH Study Group et al (2003b). Comparative efficacy and safety of atypical and conventional antipsychotic drugs in first-episode psychosis: a randomized, double-blind trial of olanzapine versus haloperidol. Am J Psychiatry 160: 1396-1404.

Malberg JE, Eisch AJ, Nestler EJ, Duman RS (2000). Chronic antidepressant treatment increases neurogenesis in adult rat hippocampus. J Neurosci 20: 9104-9110.

Markakis EA, Gage FH (1999). Adult-generated neurons in the dentate gyrus send axonal projections to field CA3 and are surrounded by synaptic vesicles. J Comp Neurol 406: 449-460.

Meltzer HY, McGurk SR (1999). The effects of clozapine, risperidone, and olanzapine on cognitive function in schizophrenia. Schizophr Bull 25: 233-255.

Miller MW, Nowakowski RS (1988). Use of bromodeoxyuridineimmunohistochemistry to examine the proliferation, migration, and time of origin of cells in the central nervous system. Brain Res 457: 44-52.

Moncrieff J (2003). Clozapine versus conventional antipsychotic drugs for treatment-resistant schizophrenia: a re-examination. Br J Psychiatry 183: 161-166.

Moratalla R, Quinn B, DeLanney LE, Irwin I, Langston JW, Graybiel AM (1992). Differential vulnerability of primate caudate-putamen and striosome-matrix dopamine systems to the neurotoxic effects of 1-methyl-4-phenyl-1,2,3,6-tetrahydropyridine. Proc Natl Acad Sci USA 89: 3859-3863.

Nilsson M, Perfilieva E, Johansson U, Orwar O, Eriksson PS (1999). Enriched environment increases neurogenesis in the adult rat dentate gyrus and improves spatial memory. J Neurobiol 39: 569-578.

Parent JM, Vexler ZS, Gong C, Derugin N, Ferriero DM (2002). Rat forebrain neurogenesis and striatal neuron replacement after focal stroke. Ann Neurol 52: 802-813.

Paxinos G, Watson C (1998). The Rat Brain in Stereotaxic Coordinates, 4th ed. Academic Press: San Diego, CA.

Radley JJ, Jacobs BL (2002). 5-HT1A receptor antagonist administration decreases cell proliferation in the dentate gyrus. Brain Res 955: 264-267.

Robertson GS, Matsumura H, Fibiger HC (1994). Induction patterns of Fos-like immunoreactivity in the forebrain as predictors of atypical antipsychotic activity. J Pharmacol Exp Ther 271: 1058-1066.

Rosenheck R, Perlick D, Bingham S, Liu-Mares W, Collins J, Department of Veterans Affairs Cooperative Study Group on the Cost-Effectiveness of Olanzapine et al (2003). Effectiveness and cost of olanzapine and haloperidol in the treatment of schizophrenia: a randomized controlled trial. JAMA 290: 2693-2702.

Santarelli L, Saxe M, Gross C, Surget A, Battaglia F, Dulawa S et al (2003). Requirement of hippocampal neurogenesis for the behavioral effects of antidepressants. Science 301: 805-809.

Selemon LD, Kleinman JE, Herman MM, Goldman-Rakic PS (2002). Smaller frontal gray matter volume in postmortem schizophrenic brains. Am J Psychiatry 159: 1983-1991.

Stanfield BB, Trice JE (1988). Evidence that granule cells generated in the dentate gyrus of adult rats extend axonal projections. Exp Brain Res 72: 399-406.

Wahlbeck K, Cheine M, Essali MA (2000). Clozapine versus typical neuroleptic medication for schizophrenia. Cochrane Database Syst Rev, (2) CD000059. 
Wakade CG, Mahadik SP, Waller JL, Chiu FC (2002). Atypical neuroleptics stimulate neurogenesis in adult rat brain. J Neurosci Res 69: 72-79.

Weickert TW, Goldberg TE, Marenco S, Bigelow LB, Egan MF, Weinberger DR (2003). Comparison of cognitive performances during a placebo period and an atypical antipsychotic treatment period in schizophrenia: critical examination of confounds. Neuropsychopharmacology 28: 1491-1500.

White NM, Hiroi N (1998). Preferential localization of selfstimulation sites in striosomes/patches in the rat striatum. Proc Natl Acad Sci USA 95: 6486-6491.
Woerner MG, Robinson DG, Alvir JM, Sheitman BB, Lieberman JA, Kane JM (2003). Clozapine as a first treatment for schizophrenia. Am J Psychiatry 160: 1514-1516.

Yang M, Stull ND, Berk MA, Snyder EY, Iacovitti L (2002). Neural stem cells spontaneously express dopaminergic traits after transplantation into the intact or 6-hydroxydopamine-lesioned rat. Exp Neurol 177: 50-60.

Youngren KD, Inglis FM, Pivirotto PJ, Jedema HP, Bradberry CW, Goldman-Rakic PS et al (1999). Clozapine preferentially increases dopamine release in the rhesus monkey prefrontal cortex compared with the caudate nucleus. Neuropsychopharmacology 20: 403-412. 